\title{
Pergeseran Tradisi Manganan Perahu
}

\author{
Lukman Al Khafidz \\ UIN Sunan Ampel Surabaya \\ lukman@yahoo.co.id
}

\begin{abstract}
Abstrac;
Tradition is a part of people's lives, there is always accompanying the journey of human life, various traditions in society are the product of human's own creation, always guarded and passed down from generation to generation. That is what happened to the tradition of manganan paerahu in the village of Palang in Tuban district, the tradition of manganan perahu which is a legacy from ancestors is always routinely carried out every year. However, along with the passage of time and the pattern of community life, the tradition of manganan perahu also experienced changes from the procedures for implementation and various equipment. The tradition of a boat mackerel that was initially syncretistic and even tended to be thick with nuances to Hindu eventually experienced a shift towards Islamic manganan perahu traditions. Strengthening the values to Islam that occurred in the community of Palang was allegedly the main factor causing the change in the implementation of the tradition of manganan perahu from culture to Hinduan to Islam.
\end{abstract}

Keyword; Shifting, Culture, Manganan Perahu

\begin{abstract}
Abstrak;
Tradisi merupakan bagian dari kehidupan masyarakat, selalu ada mengiringi perjalann kehidupan manusia, berbagai tradisi yang ada di masyarakat memrupakan hasil cipta dari manusia itu sendiri, selalu dijaga dan diwariskan secara turun temurun. Itulah yang terjadi pada tradisi manganan perahu di desa Palang kabupaten Tuban, tradisi manganan perahu yang merupakan warisan dari nenek moyang selalu rutin dilakukan setiap tahunnya. Akan tetapi seiring denga perjalanan waktu dan terjadinya pola kehidupan masyarakat, tradisi manganan perahu juga mengalami perubahan dari tata cara pelaksanaan serta berbagai perlengkapannya. Tradisi manganan perahu
\end{abstract}


yang awalnya sinkretis bahkan cenderung kental dengan nuansa ke Hinduan pada ahirnya mengalami pergeseran menuju tardisi manganan perahu yang Islami. Penguatan nilai-nilai ke Islmana yang terjadi pada masyarakat Palang disinyalir menjadi faktor utama yang menyababkan terjadinya perubahan pelaksanaan tradisi manganan perahu dari budaya ke Hinduan menjadi ke Islaman.

Kata kunci; Pergeseran, Budaya, Manganan Perahu

\section{Pendahuluan}

Kehidupan beragama adalah kenyataan hidup manusia yang ditemukan sepanjang sejarah masyarakat. Ketergantungan masyarakat pada kekuatan gaib atau yang suci ditemukan pada zaman purba sampai ke zaman sekarang, atas dasar hubungan terhadap kepercayan yang diyakini kebenarannya sehingga ia menjadi kepercayaan keagamaan atau kepercayaan religius. Sehingga mengadakan upacara upacara pada momen-momen tertentu seperti perkawinan, larung sesaji dan sedekah laut, semua moment itu berlangsung dari dahulu kala sampai zaman sekarang ini. Upacara-upacara ini dalam agama dinamakan ibadat atau ritual, ia mempunyai tempat tersendiri dan menggunakan sesuatu yang dianggap sakral ${ }^{17}$.

Perilaku keagamaan ini rutin dilakukan oleh manusia dalam rangka menjaga hubungan baik dengan yang dianggap suci, dalam hal pengalaman keagamaan Rudlf Otto mengatakan bahwa yang suci tersebut adalah kekuatan tertinggi. Apa yang terlihat didalamnya adalah sesuatu yang tak terselami dan mengatasi semua mahluk, sehingga menimbulkan implikasi ketidak berdayaan bagi penganutnya ${ }^{18}$ dan bagi Durkheim menimbulkan suatu dampak kewajiban untuk berprilaku keagamaan, ${ }^{19}$ sedangkan menurut koentjaraningrat implikasi pengalaman terhadap yang suci tersebut menimbulkan tindakan-tindakan religi. ${ }^{20}$

Tradisi untuk dipersembahkan kepada yang suci tersebut senantiasa berjalan secara turun-temurun, dalam rangka menjaga kewajiban terhadap yang suci. Akan tetapi tidak bisa dipungkiri juga bahwa sebuah tradisi yang dilakukan oleh masyarakat yang tidak pernah lepas dari pengaruh kebudayaan luar serta tantangan perubahan sosial masyarakat. Artinya perubahan masyarakat mempengaruhi terhadap adanya perubahan sosial, ${ }^{21}$ perubahan sosial yang dimaksud adalah bisa dalam rangka menggeser hal-hal yang sudah ada, menggantikannya, mentransformasikannya, atau

17 Bustanuddin Agus, Agama dalam kehidupan Manusia, Pengantar Antropologi Agama, (Jakarta : Raja Grafindo Persada, 2007).

18 Thomas F O'dea, sosiologi agama; suatu pengantar awal (Jakarta:CV Rajawali, 1992) 38-39

${ }^{19}$ Koentjaraningrat, Pengantar Antropologi; Pokok - pokok Etnografi (Jakart: Rineka Cipta, 1998) 201.

${ }^{20}$ Koentjaraningrat, Pengantar Ilmu Antrpologi (Jakarta: Rineka Cipta, 1990) 377.

${ }^{21}$ Harsojo, Pengantar Antropologi (Jakarta: Abardi, 1984) 154. 
menambahkan yang baru yang kemudian disandingakan dengan hal-hal yang sudah ada. $^{22}$

Dialektika kebudayaan yang seperti ini akan senantiasa terus berjalan dan tidak akan pernah berhenti selama manusia masih ada. Sehingga bergerak dari satu generasi ke generasi penerus berikutnya, oleh karena itu kebudayaan bukanlah suatu hal yang statis, namun selalu berubah. ${ }^{23}$ Proses perubahan ini selalu menghantui kebudayaan yang ada dilingkungan masyarakat, jadi dapat dikatakan bahwa kebudayaan yang sekarang ini kita lihat sudah menjadi bagian dari sinkretisme berbagai kebudayaan, hal yang sama juga melanda kebudayaan masyarakat Jawa. Melihat pekembangan kebudayaan jawa pada fase pra Hindu-Budha, tampak bahwa kepercayaan masyarakat pada sesuatu yang gaib, misteri hanya bersifat dugaan yang berawal dari keterbatasan mereka memahami fenomena alam yang mengiringi harapanya untuk bisa hidup secara lebih baik dan sejahtera. Begitu datang ajaran baru dengan landasan yang lebih kuat, karena ditopang oleh pengalaman para penyerunya di samping juga adanya ajaran yang berdasarkan kepada kitab suci, masyarakat Jawa lebih percaya dan meyakininya sebagai sesuatu lebih benar, tanpa menghilangkan kesan-kesan dan pengalaman yang didapat dalam praktek keberagamaan sebelumnya.

Sementara itu, ditengah perjalanan kepemelukan hindhu-budha yang mereka yakini, mereka juga tetap bersifat terbuka untuk menerima agama dan tradisi yang baru, karena mereka memilki anggapan bahwa semua agama baik dan benar, yang penting pengalaman ajarannya harus didekasikan bagi kepentingan dan kemaslahatan masyarakat secara kolektif. Agami ageming aji $i^{24}$, agama harus memegang prinsip keterhormatan dan itu terletak diantaranya pada sikap sosial yang koperatif. ${ }^{25}$ Sikap koperatif ini, di tengah masyarakat Jawa saat itu diwujudkan dengan kebudayaan yang bersifat sangat sinkretis, yaitu bersifat momot atau memuat, dimana setiap agama diterima dengan sikap terbuka tanpa memperhatikan aspek benar salahnya.

Seperti juga ketika Hindhu-Budha datang ke tanah jawa, ketika Islam masuk, di tangan para cendikiawan jawa yang terlibat dalam lingkaran ke kuasaan, Islam dimodifikasi dengan keyakinan yang telah mapan sebelumnya, animisme-dinamisme dan juga Hindhu-Budha. Memang sejak Islam menguasai tanah Jawa, ia telah menjadi bagian yang tak terpisahkan dari kehidupan para cendikiawan dan ningrat dalam segala aspek. Bagi cendikiawan, Islam dengan konsep ajaranya yang lebih lengkap dan rinci menjadi sumber inspirasi dalam memproduksi karya-karyanya. Sedangkan bagi para penguasa, dari pangeran di daerah pinggiran sampai raja di pusat kekuasaan, Islam tampaknya memberi angin segar terus berkuasa bahkan juga untuk mendapatkan kekuasaan yang lebih besar. ${ }^{26}$

22 Masimambow, Koentjaraningrat dan Antropologi di Indonesia, (Jakarta:Yayasan Obor Indonesia, 1997) 9.

${ }^{23}$ Sjafri Sairin, Perubahan Sosial Masyarakat Indonesia (Yogyakarta : Pustaka Pelajar, 2002) 184.

${ }^{24}$ Muhammad Damami, Makna Agama dalam Masyarakat Jawa (Yogyakarta: LESFI, 2002) 70-71.

25 Ahmad khalil, Islam jawa, sufisme dalam etika dan tradisi jawa,(UIN-Malang Press: SUKSES Offset, 2008) 145

26 Ahmad khalil, 146 
Sejak itu muncul akulturasi model baru lagi, setelah sebelumnya kebudayaan Jawa dan hindhu-budha, kini Jawa, hindhu-budha, dan Islam. Kebudayaan istana yang bercorak hindhu-Jawa bersentuhan dengan kebudayaan Islam. Tradisi sedekah laut merupakan salah satu bentuk contoh upacara ritual yang berkembang sejak zaman Hindu-Budha menuju kearah Islam Jawa, sehingga pengaruh keberadaan berbagai agama yang ada ini melahirkan bentuk baru dari upacara sedekah laut, Islam sebagai agama terahir yang memberikan pengaruh yang cukup besar terhadap perubahan upacara sedekah laut, sedekah laut yang pada awalnya berlandaskan pada konsep Hindu secara perlahan mengalami perubahan menuju konsep ke Islaman, hal ini tidak lepas dari semakin berkembangnya agama Islam di lingkungan masyarakat Jawa khususnya dan Nusantara pada umumnya.

Sedekah laut yang kemudian dalam masyarakat di Desa Palang kabupaten Tuban di beri nama dengan "manganan perabu" cenderung masih di lakukan setiap tahunnya, bahkan pelaksanaan acara ini sudah menjadi salah satu agenda pariwisata bagi masyarakat di kecamatan Palang ${ }^{27}$.

Upacara manganan perahu merupakan tradisi turun temurun dari nenek moyang masyarakat Palang Tuban, mulai sejak dahulu berkembangnya agama Hindu sampai sekarang yang sudah beragama Islam, keberagamaan masyarakat Desa Palang memberikan pengaruh yang besar terhadap konsepsi pelaksanaan upacara manganan perahu, perubahan konsep ritual dari Hindu ke Islam menjadi titik perhatian penelitian.

\section{Konsep Budaya}

Secara umum budaya sendiri Budaya atau kebudayaan berasal dari bahasa sansekerta yaitu buddhayah, yang merupakan bentuk jamak dari buddhi (budi atau akal) diartikan sebagai hal- hal yang berkaitan dengan budi dan akal manusia, dalam bahasa inggris kebudayaan disebut culture yang berasal dari kata latin colere yaitu mengolah atau mengerjakan dapat diartikan juga sebagai mengolah tanah atau bertani, kata culture juga kadang sering diterjemahkan sebagai "Kultur" dalam bahasa Indonesia ${ }^{28}$.

Geertz dalam bukunya "Mojokuto; Dinamika Sosial Sebuah Kota di Jawa", mengatakan bahwa budaya adalah suatu sistem makna dan simbol yang disusun dalam pengertian dimana individu- individu mendefinisikan dunianya, menyatakan perasaannya dan memberikan penilaian- penilaiannya, suatu pola makna yang ditransmisikan secara historis, diwujudkan dalam bentuk- bentuk simbolik melalui sarana dimana orang- orang mengkomunikasikan, mengabdikan, dan mengembangkan pengetahuan, karena kebudayaan merupakan suatu sistem simbolik maka haruslah dibaca, diterjemahkan dan diinterpretasikan ${ }^{29}$.

${ }^{27}$ Linus Suryadi, SG, Regol Megal megol, Fenomena Kosmologi jawa, (Jogjakarta: Andi Offset, 1993) 14. ${ }^{28}$ Ibid, 153

${ }^{29}$ Tasmuji, Dkk, Ilmu Alamiah Dasar, Ilmu Sosial Dasar, Ilmu Budaya Dasar, (Surabaya: IAIN Sunan Ampel Press, 2011) 154. 
Seorang antopolog Inggris Edward B. Taylor (1832-1917) ${ }^{30}$ mengatakan bahwa kultur adalah keseluruhan yang kompleks termasuk didalamnya pengetahuan, kepercayaan, kesenian, moral, hukum adat dan segala kemampuan dan kebiasaan lain yang diperoleh manusia sebagai seorang anggota masyarakat ${ }^{31}$.

Ralph Linton yang memberikan definisi kebudayaan yang berbeda dengan perngertian kebudayaan dalam kehidupan sehari- hari kebudayaan adalah seluruh cara kehidupan dari masyarakat dan tidak hanya mengenai sebagian tata cara hidup saja yang dianggap lebih tinggi dan lebih diinginkan",32

Salah seorang guru besar antropologi Indonesia Kuntjaraningrat berpendapat bahwa "kebudayaan" berasal dari kata sansekerta buddhayah bentuk jamak dari buddhi yang berarti budi atau akal, sehingga menurutnya kebudayaan dapat diartikan sebagai hal- hal yang bersangkutan dengan budi dan akal, ada juga yang berpendapat sebagai suatu perkembangan dari majemuk budi- daya yang artinya daya dari budi atau kekuatan dari akal ${ }^{33}$.

Masih menurut koenjtaraningrat berpendapat bahwa unsur kebudayaan mempunyai tiga wujud, yaitu pertama sebagai suatu ide, gaagsan, nilai- nilai normanorma peraturan dan sebagainya, kedua sebagai suatu aktifitas kelakuan berpola dari manusia dalam sebuah komunitas masyarakat, ketiga benda- benda hasil karya manusia $^{34}$.

Sementara Selo Soemardjan dan Soeleman Soemardi merumuskan kebudayaan sebagai semua hasil karya, rasa dan cipta masyarakat. Karya masyarakat menghasilkan teknologi dan kebudayaan kebendaan atau kebudayaan jasmaniah yang diperlukan oleh manusia untuk menguasai alam sekitarnya agar kekuatan serta hasilnya dapat diabadikan untuk keperluan masyarakat. ${ }^{35}$

Menurut Koentjaraningrat, istilah universal menunjukkan bahwa unsur-unsur kebudayaan bersifat universal dan dapat ditemukan di dalam kebudayaan semua bangsa yang tersebar di berbagai penjuru dunia. Ketujuh unsur kebudayaan tersebut adalah $:{ }^{36}$

\footnotetext{
${ }^{30}$ Edward B. Tylor adalah orang Inggris yang mula-mula mendapatkan pendidikan dalam kesusastraan dan peradaban Yunani dan Rum klasik yang kemudian tertarik pada dunia etnografi dan mulai melakukan beberapa kajian terkait fenomena keagamaan, salah satu bukunya yang terkenal adalah Primitive Culture; Research into the Development of Mythology, Philosophy,Religion, Language, Art and Custom (1874), dalam Koenjtaraningrat, Sejarah Teori Antropologi I (Jakarta : UI Press, 1987) 48.

${ }^{31}$ William A. Haviland, Antropologi, Jilid 1 (Jakarta: Erlangga, 1985), 332.

32 Tasmuji, Dkk, Ilmu Alamiah Dasar, Ilmu Sosial Dasar, Imu Budaya Dasar, (Surabaya: IAIN Sunan Ampel Press, 2011), 151.

${ }^{33}$ Koentjaraningrat, Kebudayaan, Mentalitas dan Pembangunan, (Jakarta: Gramedia Pustaka Utama, 1993), 9 .

${ }^{34}$ Ibid, 5.

${ }^{35}$ Jacobus Ranjabar, Sistem Sosial Budaya Indonesia; Suatu Pengantar (Bogor: Ghalia Indonesia, 2006) 21.

36 Tasmuji, Dkk, Imu Alamiah Dasar, Ilmu Sosial Dasar, Imu Budaya Dasar, (Surabaya: IAIN Sunan Ampel Press, 2011), 160-165. Lihat pula Jacobus Ranjabar, Sistem Sosial Budaya Indonesia; Suatu Pengantar (Bogor : Ghalia Indonesia, 2006) $20-23$.
} 
1. Sistem Bahasa; Bahasa merupakan sarana bagi manusia untuk memenuhi kebutuhan sosialnya untuk berinteraksi atau berhubungan dengan sesamanya. Menurut Keesing, kemampuan manusia dalam membangun tradisi budaya, menciptakan pemahaman tentang fenomena sosial yang diungkapkan secara simbolik, dan mewariskannya kepada generasi penerusnya sangat bergantung pada bahasa. Dengan demikian, bahasa menduduki porsi yang penting dalam analisa kebudayaan manusia.

2. Sistem Pengetahuan; Sistem pengetahuan dalam kultural universal berkaitan dengan sistem peralatan hidup dan teknologi karena sistem pengetahuan bersifat abstrak dan berwujud di dalam ide manusia. Sistem pengetahuan sangat luas batasannya karena mencakup pengetahuan manusia tentang berbagai unsur yang digunakan dalam kehidupannya.

3. Sistem Sosial; Unsur budaya berupa sistem kekerabatan dan organisasi sosial merupakan usaha antropologi untuk memahami bagaimana manusia membentuk masyarakat melalui berbagai kelompok sosial. Menurut Koentjaraningrat tiap kelompok masyarakat kehidupannya diatur oleh adat istiadat dan aturan-aturan mengenai berbagai macam kesatuan di dalam lingkungan di mana dia hidup dan bergaul dari hari ke hari. Kesatuan sosial yang paling dekat dan dasar adalah kerabatnya, yaitu keluarga inti yang dekat dan kerabat yang lain.

4. Sistem Peralatan Hidup dan Teknologi; Manusia selalu berusaha untuk mempertahankan hidupnya sehingga mereka akan selalu membuat peralatan atau benda-benda tersebut. Perhatian awal para antropolog dalam memahami kebudayaan manusia berdasarkan unsur teknologi yang dipakai suatu masyarakat berupa benda-benda yang dijadikan sebagai peralatan hidup dengan bentuk dan teknologi yang masih sederhana.

5. Sistem Mata Pencaharian Hidup; Mata pencaharian atau aktivitas ekonomi suatu masyarakat menjadi fokus kajian penting etnografi. Penelitian etnografi mengenai sistem mata pencaharian mengkaji bagaimana cara mata pencaharian suatu kelompok masyarakat atau sistem perekonomian mereka untuk mencukupi kebutuhan hidupnya.

6. Sistem Religi; fungsi religi dalam masyarakat adalah adanya pertanyaan mengapa manusia percaya kepada adanya suatu kekuatan gaib atau supranatural yang dianggap lebih tinggi daripada manusia dan mengapa manusia itu melakukan berbagai cara untuk berkomunikasi dan mencari hubungan-hubungan dengan kekuatan-kekuatan supranatural tersebut.

7. Kesenian; Deskripsi yang dikumpulkan dalam penelitian tersebut berisi mengenai benda-benda atau artefak yang memuat unsur seni, seperti patung, ukiran, dan hiasan. Penulisan etnografi awal tentang unsur seni pada kebudayaan manusia lebih mengarah pada teknikteknik dan proses pembuatan benda seni tersebut. Selain itu, deskripsi etnografi awal 
tersebut juga meneliti perkembangan seni musik, seni tari, dan seni drama dalam suatu masyarakat. ${ }^{37}$

\section{Tumpeng Sebagai Medan Budaya Manganan Perahu}

Tumpeng adalah cara penyajian nasi beserta lauk-pauknya dalam bentuk kerucut; karena itu disebut pula 'nasi tumpeng'. Olahan nasi yang dipakai umumnya berupa nasi kuning, meskipun kerap juga digunakan nasi putih biasa atau nasi uduk. Cara penyajian nasi ini khas Jawa atau masyarakat Betawi keturunan Jawa dan biasanya dibuat pada saat kenduri atau perayaan suatu kejadian penting. Meskipun demikian, masyarakat Indonesia mengenal kegiatan ini secara umum dalam berbagai prosesi ritual keagamaan.

Tumpeng selalu menjadi pelengkap dalam berbagai pelaksanaan upacara keagamaan, sebut saja slametan, kendurenan, procotan, dan berbagai tradisi lingkaran hidup yang lain. Penggunaan tumpeng dalam berbagai ritual keagamaan dimaksudkan untuk memohon pertolongan kepada Yang Maha Pencipta agar kita dapat memperoleh kebaikan dan terhindar dari keburukan, serta memperoleh kemuliaan yang memberikan pertolongan. Dan itu semua akan kita dapatkan bila kita mau berusaha dengan sungguh-sungguh.

Persepsi makna penggunaan tumpeng dalam berbagai acara keagamaan tersebut telah berjalan secara turun temurun dan tetap dilestarikan oleh generasi penerus, tidak heran kalau tumpeng selalu digunakan dalam setiap acara keagamaan hal ini dikarenakan bentuknya yang tinggi keatas melambangkan permohonan dan pengakuan terhadap adanya yang maha tinggi.

Tumpeng merupakan bagian penting dalam perayaan kenduri tradisional. Perayaan atau kenduri adalah wujud rasa syukur dan terima kasih kepada Yang Maha Kuasa atas melimpahnya hasil panen dan berkah lainnya. Karena memiliki nilai rasa syukur dan perayaan, hingga kini tumpeng sering kali berfungsi menjadi kue ulang tahun dalam perayaan pesta ulang tahun.

Tumpeng juga ditemukan dalam tradisi pelaksanaan manganan perahu di desa Palang, masyarakat sudah percaya bahwa penggunaan tumpeng dalam tradisi mangan perahu merupakan kelengkapan wajib yang harus di buat oleh ibu-ibu desa.

Pada pagi hari setiap kelompok nelayan masyarakat desa Palangpada saat pelaksanaan upacara manganan perahu membuat dua tumpeng,kedua tumpeng tersebut dibawah ke TPI, setelah selesai didoa'akan oleh Modin (tokoh agama dalam tradisi Islam), satu tumpeng ditaruh di tempat pelelangan ikan (TPI) dan tumpeng yang satu di bawah ke perahu.

Didalam tumpeng selain ada nasi yang menjulang tinggi ke atas juga terdapat lauk pauknya seperti ikan asin, tahu, tempe, ikan ayam, serundeng, urapan dan juga jajanan pasar sebagai pelengkap di sekitar tumpeng, bahkan terkadang juga

37 Baca dalam Mohammad Thoriqul Huda,"Harmoni Sosial dalam Tradisi Sedekah Bumi Masyarakat Desa Pancur Bojonegoro", Religio, Vol. 7 No. 2 2017, 82-106. 
ditambahkan buah-buahan yang disajikan di atas tampah (tempat bundar yang terbuat dari anyaman bambu) yang di beri alas daun pisang. ${ }^{38}$

Terkadang untuk isi pelengkap tumpeng setiap kelompok nelayan berbedabeda, tergantung dari selera ibu-ibu yang memasak, hal ini karena memang tidak ada unsur yang diwajibkan dalam penyajian tumpeng, yang terpenting adalah bentuknya menjulang ke atas disertai dengan adanya lauk pauk dan jajanan pasar serta buahbuahan sebagai pelengkap tumpeng.

Selanjutnya larung tumpeng, Larung tumpeng adalah peristiwa dimana tumpeng yang sudah dido'akan oleh modin (tokoh agama dalam tradisi Islam) di tempat pelelangan ikan bersama warga masyarakat. Tumpeng yang sudah didoakan tersebut kemudian dibawah oleh masing-masing kelompok nelayan ke perahu dan kemudian dibawa menggunakan perahu ke tengah laut, sesampai di tengah laut tmpeng tersebut kemudian di taruh di atas air laut dan dibiarkan terombang ambing sembari berharap mudah-mudahan diberikan kemudahan untuk mencari rizki di laut.

Pelepasan tumpeng di tengah laut tersebut dilakukan oleh semua kelompok nelayan desa Palang, bergerak bersama-sama menuju tengah laut di sore hari, dan sebagian warga yang lainnya menyaksikan di tepi pantai. Setelah melaksanakan larung tumpeng di tengah laut masing-masing kelompok nelayan kembali ke darat untuk ikut serta mempersiapkan pelaksanaan pengajian yang rutin dilakukan disetiap malamnya.

Larung tumpeng selain disaksikan oleh masyarakat desa Palang, juga selalu dihadiri oleh warga desa sekitar yang memang tertarik untuk melihat prosesi tersebut. Hal ini memberikan manfaat dibidang pariwisata bagi masyarakat desa Palang, meskipun warga yang datang menyaksikan tidak dipungut biaya namun bagi warga desa Palang mampu mengenalkan sejarah dan tradisi desa pada masyarakat sekitar sudah merupakan suatu kebanggan yang luar biasa.

Dalam rangkaian sejarah manganan perahu, pada zaman dahulu pelaksanaan larung tumpeng selalu disertai dengan menggunakan kepala kerbau, hal ini terjadi ketika masyarakat desa Palang masih kental dengan symbol ke Hinduan. Akan tetapi seiring dengan berjalannya waktu tradisi larung kepala kerbau tersebut mulai ditinggalkan, menurut penuturan masyarakat Palang perubahan tradisi dengan tidak lagi menggunakan kepala kerbau sebagai bagian dari prosesi larung terjadi ketika nilainilai ke Islaman sudah mengakar penuh. Semakin mengakarnya nilai-nilai ke Islaman tersebut ditandai dengan berbagai hal diantaranya semakin banyaknya Musholla yang berdiri di desa Palang, banyak dari orang tua yang memberikan pendidikan anaknya di pesantren.

Penguatan nilai-nilai ke Islaman memberikan pengaruh besar terhadap prosesi pelaksanaan larung tumpeng, dari awalnya yang masih sangat kental dengan nuansa ke Hinduan namun secara perlahan dan pasti mulai bergeser pada konsepsi

38 Tuban, Indah, Wawancara. 
Islam. Proses perubahan kultur ini niscaya akan dapat ditemukan dalam berbagai peristiwa seiring dengan terjadinya kontak kebudayaan dalam masyarakat.

Kemudian diahiri dengan makan tunpeng, Seperti yang sudah diungkapkan di atas bahwa masyarakat desa Palang membuat dua tumpeng, kedua tumpeng tersebut dido'akan di tempat pelelangan ikan (TPI). Tumpeng yang pertama setelah dido'akan dibawah oleh masing-masing kelompok nelayan untuk dilarung ke tengah laut, sedangkan tunpeng yang satunya tetap ditaruh di TPI untuk dimakan bersama.

Prosesi makan tumpeng bersama ini adalah bagian dari prosesi yang ditunggu-tunggu oleh masyarakat, karena bisa makan tumpeng secara ramai-ramai adalah hal yang sulit bisa dilakukan dan hanya pada saat manganan perahu hal itu bisa terjadi. $^{39}$

Banyak dari warga yang membawa anaknya untuk hadir di TPI hanya ntuk melakukan makan tumpeng bersama-sama, tradisi membawa anak dalam setiap prosesi makan tumpeng ini lazim dilakukan oleh ibu-ibu dalam rangka memberikan pengetahuan kepada generasi penerus untuk memahami tradisi yang sudah dilakukan secara turun-temurun.

Makan tumpeng bersama-sama ini juga menjadi symbol kerukunan serta rasa guyub antar masyarakat desa Palang. Setidaknya pada momen ini masyarakat sudah melupakan idenntitas individu mmereka dan melebur menjadi satu kesatuan bersama pada satu medan kerukunan.

\section{Pergeseran Nilai dan Penyebabnya}

Tardisi manganan perahu pada awal mula adalah hasil dari sinkretisme terhadap budaya Hindu, pada awal pelaksanaannya tradisi ini kental sekali dengan nuansa ke Hinduan dan animisme, hal ini ditunjukan dari berbagai barang yang dan perlengkapan yang digunakan dalam melaksnaakan manganan perahu.

Seperti yang sudah di bahas sebelumnya bahwa manganan perahu pada awal mulanya menggunakan kepala kerbau sebagai pelengkap uatama dalam melaksanakan manganan perahu, dalam tradisi Hindu penggunaan kepala kerbau untuk melakuka ritual atau upacara adalah menjadi hal yang lumrah untuk dilakukan. Penggunaan kepala kerbau dalam tradisi masyarakat Hindu dipergunakan dalam upacara dalam rangka memberikan persembahan kepada penguasa laut berupa pengorbanan dengan harapan mudah-mudahan diberikan kelancaran dalam mencari rezeki di laut.

Namun tradisi niscaya akan selalu berubah seiring denga berubahnya waktu dan perubahan yang terjadi pada masyarakat (pelaku tradisi), berkembangnya Islam di tanah Jawa memberikan pengaruh yang besar terhadap keberadaan tradisi-tradisi masyarakat yang masih bernuansa ke Hinduan, dalam beebrapa kasus yang terjadi pada beberapa tradisi seperti tardisi sedekah bumi, tradisi sedekah laut dan beberapa

39 Tuban, H.suwarno, Wawancara. 
tradisi lain yang ada pada masyarakat juga berubah seiring dengan menguatnya ajarn Islam.

Dalam perubahan tradisi tidak serta merta berlangsung dengan cepat, perubahan tradisi selalu terjadi secara perlahan seiring denga berjalannya waktu. Perubahan juga tidak serta langsung secara menyeluruh akan tetapi terjadi secara bertahap.

Dalam tardisi manganan perahu yang dilakukan oleh masyarakat desa Palang, perubahan dari tardisi ke Hinduan menuju ke Islaman juga terjadi, hal ini dikarenakan semakin menguatnya nilai-nilai ke Islaman pada diri masyarakat.

Manganan perahu pada awal mulanya menggunakan kepala kerbau namun karena intensitas ke Islaman mulai menguat tradisi mangana perahu juga mengalami perubahan, perubahan tersebut mulai dirasakan sejak sekitar tahun 1990 an, jika sejak pertama kepala kerbau sealu digunakan dalam praktik manganan perahu namun setelah periode 1990 an penggunaan kepala kerbau mulai tidak lagi digunakan. Hal ini seiring dengan semakin menguatnya nilai-nilai ke Islaman yang kemudian berpengaruh pada tingkah laku masyarakat desa Palang, tidak terkecuali pada pelaksanaan tradis manganan perahu. Pemurnian ajaran Islam dalam tradisi menganan perahu juga terjadi, hal ini ditunjukkan dengan tidak lagi digunakannya kepala kerbau sebagai bagian dari rangkaian tradisi mangana perahu, hal ini dikarenakan anggapan masyarakat bahwa kepala kerbau adalah bagian dari tradisi ritual ke Hinduan sehingga tidak ccok dengan tradisi ke Islaman.

Padahal jika kita mengacu pada tradisi Islam murni, Islam juga tidak pernah mengajarkan umatnya untuk melaksanakan tradisi manganan perahu, dalam sejarah Islam tidak pernah ada contoh tentang pelaksanaan ritual seprti manganan perahu, sehingga jika dipahami lebih mendalam bahwa tradisi manganan perahu secara keseluruhan adalah warisan dari budaya Hindu Jawa yang kemudian bersentuhan dengan Islam. Secara perlahan proses Islamisasi terhadap pelaksanaan manganan perahu akan terus terjadi, jika penguatan Islam pada sekitar tahun 1990 an mampu mengubah tradisi penggunaan kepala kerbau dalam manganan perahu, maka bisa sangat mungkin dengan selalu menguatnya nilai-nilai ke Islaman maka perubahanperubahan yang lain juga akan terjadi pada pelaksnaaan manganan perahu.

Namun dewasa ini masyarakat mulai paham dengan Islam Jawa yang berbeda denga Islam sebagaimana di tanah kelahirannya (Arab). Islama Jawa mempertemukan tradisi Jawa dengan Islam, kedua tradisi tersebut saling melengkapi, Islam sebagai nafas dan tradisi Jawa sebagai kerangkannya, oleh karena itu, sejatinya traidisi manganan perahu yang sekarang ini memrupakan hasil sinkretisme antara budaya denagan Islam karena nilai kehinduannya sudah memudar.

Dalam memahami penyebab terjadinya pergeseran tradisi manganan perahu dari ke Hinduan menjadi ke Islaman perlu kita ketahui bersama bahwa faktor utamanya adalah menguatnya nilai-nilai ke Islaman yang terjadi pada masyarakat desa Palang, sehingga dalam konteks ini kita akan mencoba mengkaji beberapa faktor yang 
terjadi di lapangan yang mendorong terjadinya penguatan nilai-nilai ke Islaman pada masyarakat desa Palang.

Penguatan nilai-nilai ke Islaman ini terjadi karena beberapa factor yang, diantaranya:

1. Modernisasi.

Modernisasi dapat diduga sebagai salah satu faktor yang menyebabkan terjadinya pergeseran manganan perahu. Seperti dikatakan Gellner ${ }^{40}$ para sosiolog yang telah lama akrab dan sering membenarkan teori sekularisasi mengatakan bahwa dalam masyarakat ilmiah-industri, iman dan amalan agama meunurun. Banyak argumen yang dapat dikedepankan untuk memberi topangan intelektual atas pandangan tersebut, dapat pula dalam hal ini dikedepankan bukti-bukti empiris. Tetapi, harus ada pengecualian yang dramatis dan mencolok, yaitu Islam. Menganggap sekularisasi telah melandah Islam tidaklah berlebihan. Namun anggapan itu salah, sebab saat ini Islam tetap kuat seperti seabad yang lampau, bahkan mungkin lebih kuat.

Tanggapan ini tidak memperdebatkan mengapa agama tertentu tahan terhadap gelombang serkularisasi, sementara yang lain tidak. Tetapi untuk menunjukkan bahwa meskipun arus deras modernisasi melanda bumi indonesia hal itu hal itu tidak serta merta menyebabkan memudarnya nilai-nilai Islam, tetapi Islam justru semakin menguat baik sebagai kekuatan kultural, sosial maupun politik. Munculnya Islam sebagai kekuatan baru ini sudah barang tentu diikuti oleh semakin menguatnya pengamalan nilai-nilai Islam. Hal ini memang tidak digeneralisir sebagai sesuatu gejala makro di seluruh dunia Islam. Paling tidak gejala tersebut relevan untuk konteks masyarakat indonesia. Sebab, sebagai umat yang terbesar, mereka yang paling banyak bersentuhan dengan modernisasi berarti mereka pula yang akan banyak tersekularkan. Kenyataanya, umat Islam Indonesia mengalami kebangkitan baik secara intelektual maupun keberagamaannya secara utuh.

Dimana letak kolerasi modernisasi dengan pergeseran budaya yang terjadi pada masyarakat desa Palang. Modernisasi sebagai pradigma pembangunan dapat diartikan sebagai suatu proses komprehensif pertumbuhan ekonomi, mobiltas sosial dan perluasan budaya ${ }^{41}$. Perekonomian indonesia telah menunjukkan angka-angka perkembangan yang sangat berarti, meskipun banyak kekurangan yang mesti harus dibenahi. Masyarakat mengalami mobilitas sosial baik vertikal maupun

40 Ernest Gellner, Menolak Post Modernisme Antara Fundamentalisme Rasinalisme dan Fundamentalisme Religius, Alih Bahasa : Hendro Prasetyo dan Nurul Agustina, (Bandung : Mizan, 1994) 16-17.

41 Abraham, Modernisasi di Dunia Ketiga; Suatu Teori Pembangunan, Ahli Bahasa : Rusli Karim, (Yogyakarta : Tiara Wacana, 1991) 195. 
horisontal secara besar-besaran. Kondisi perekonomian pada masa orde baru yang semakin baik telah memberikan kesempatan kepada masyarakat untuk mengakses dunia pendidikan, melaksanakan ajaran agamanya dan juga sumber-sumber informasi. Kondisi ini mendapatkan dukungan dengan semakin meningkatnya fasilitas-fasilitas sosial dari waktu ke waktu. Semakin luas kesmpatan untuk masuk keberbagai jenis dan jenjang pendidikan, termasuk juga melaksanakan perintah agama, misalnya menunaikan ibadah haji. Seperti banyak disinyalir oleh pengamat dan juga birokrat, bahwa meningkatnya jumlah jamaah haji yang pesat adalah karena semakin membaiknya kondisi perekonomian masyarakat. Penting dicatat disini bahwa mereka berasal dari berbagai lapisan tentu tentu ada yang semula masih bisa dikategorikan minim pengetahuan Islamnya. Modernisasi selain mendorong berbagai kemajuan dan perubahan kearah yang lebih dinamis, juga menyebabkan memudarnya nilai-nilai tradisional di masyarakat.

Menurut penuturan masyarakat desa Palang bahwa kondisi perekonomian masyarakat pada tahun 1980 an masih dibawah standar atau bisa dikatakan masyarakat menengah ke bawah, masyarakat desa Palang yang mayoritas adalah nelayan masih menggunakan perlatanperalatan tradisional dalam menangkap ikan di laut. Namun seiring dengan berjalannya waktu dan semakin modern peralatan masyarakat nelayan, masyarakat desa Palang bisa meraup hasil yang maksimal dari laut, peralatan yang modern membuat masyarakat lebih mudah dalam menangkap ikan. ${ }^{42}$

Perekonomian yang stabil tersebut mampu mengangkat taraf kesejahteraan masyarakat desa Palang, sehingga mereka dengan mudah mampu untuk menjalankan rukun Islam yang kelima yakni berangkat Haji ke tanah suci, dari waktu ke waktu semakin banyak masyarakat desa Palang yang berangkat ke tanah suci Makkah untuk menjalankan ritual Islam tersbut.

Penguatan nilai-nilai ke Islaman ini berdampak pada tardisi-tardisi masyarakat desa Palang, diantarnya menyebabkan lunturnya tardisi ke Hinduan yang ada pada tradisi manganan perahu, tradisi ke Hinduan ditandai dengan penggunaan kepala kerbau pada prosesi larung tumpeng yang sudah dilakukan oleh masyarakat desa Palang secara turun temurun, namun seiring denga pesatnya perkembangan Islam di desa Palang, penggunaan kepala kerbau mulai ditinggalkan karena masyarakat sudah memahami bahwa hal tersebut identik dengan tradisi ke Hinduan.

2. Sebab-sebab Politik.

${ }^{42}$ Tuban 
Pada awal orde baru terjadi perkembangan baru. Perubahan politik yang ditimbulkan oleh gelombang anti PKI ternyata menghancurkan kantong-kantong sosial kebudayaan masyarakat yang masih bisa dikatakan minim pengetahuan Islam (abangan) ${ }^{43}$. Organisasiorganisasi kaum abangan juga mengalami krisis setelah partai-partai yang didukung oleh kaum abangan, seperti PKI dan PNI sayap-kiri yang didukung oleh organisasi-organisasi anti-muslim dilarang atau dibubarkan.

Sejak kegagalan PKI tahun 1965 jumlah kaum komunis dan ateis menurun secara terus menerus salah satu faktor yang menyebabkan antara lain memang faktor politik. Dengan mengutip Geertz, ditegaskan pula, gelombang anti komunisme berarti bahwa seseorang yang tidak memeluk salah satu diantara agama yang diakui pemerintah pasti dituduh ateis, yang berarti komunis, dan juga berati layak dihukum mati atau dipenjara. Dalam penelitian bambang di desa Tegalroso Jawa Tengah, sejak tahun 1965 pengaruh budaya santri terus meningkat yang membuahkan banguna-bangunan tempat ibadah. Hal ini menurutnya lebih tepat dipahami sebagai fenomena kebangkitan agama dalam konteks sosial politik. Namun itu semua tidak dapat dipahami sebagai sematamata pemenuhan kebutuhan politik, tetapi juga dapat dikatakan sebagai indikator kebangkitan keagamaan yang asli dikalangan penduduk desa ${ }^{44}$.

Kondisi tersebut juga memberikan pengaruh terhadap kehidupan keberagamaan masyarakat desa Palang, dimana masyarakat berbondongbondong memperkuat nilai-nilai ke Islamannya karena takut dianggap sebagai paham komunis. Karena pada zaman dahulu siapa yang berpaham komunis maka mereka akan diculik dan diasingkan keluar desa. Secara tidak langsung kondisi politik menjadi pendorong dari menguatnya nilainilai ke Islaman.

3. Kebijakan Dibidang Pendidikan

Kebijakan nasional yang memasukkan pendidikan agama mulai dari Sekolah Dasar sampai perguruan tinggi mempunyai pengaruh yang besar pada pemahaman masyarakat tentang Islam. Dalam hal ini penting untuk dicatat, bahwa kebijakan pendidikan nasional setelah tahun 1950-an yang telah memasukan mata pelajaran agama ke dalam kurikulum di sekolah umum memberikan pengaruh yang besar terhadap penguatan pemaham masyarakat secara umum terhadap ajaran Islam. Hal itu merata pada semua lapisan masyarakat, tidak terkecuali masyarakat desa Palang.

43 Dalam bahasa yang digunakan Geertz abangan adalah kategori untuk masyarakat yang masih memegang teguh sinkretisme antara Islam dan Budaya Hindu atau Animisme, artinya masyarakat abangan adalah masyarakat yang belum menjalankan secara murni, Geertz, Abangan, Santri, Priyai dalam Masyarakat Jawa,(Jakarta : Dunia Pustaka Jaya, 1981).

${ }^{44}$ Muzani Saiful, Pembangunan dan Kebangkitan Islam di Asia Tenggara (Jakarta : LP3ES, 1993), 190. 
Kebijakan yang mengatur diwajibkannya ajaran agama dalam sekolah menjadi rintisan penting untuk mengajarkan Islam pada generasi penerus, meskipun secara non formal (di luar bangku sekolah) masyarakat juga menerima pengajaran tentang Islam, namun pengajaran di sekolahan juga tidak kalah memiliki peran yang penting dalam rangka memberikan pengetahuan secara mendasar tentang agama Islam.

4. Elit Islam

Dalam sejarah pengIslaman di tanah jawa memiliki peran yang paling penting. Elit Islam terdiri dari kyai baik yang memangku pesantren. Langgar atau tidak. Termasuk ulama dan pemuka-pemuka Islam, disebut pemuka-pemuka Islam sebab meraka dalam tradisi masyarakat Islam tidak disebut kyai atau ulama tetapi jutga berperan dalam usaha-usaha penyiaran Islam. Dalam tradisi mayarakat Islam di jawa, sebutan kyai diberikan kepada seseorang ahli pengetahuan Islam yang memiliki atau menjadi pimpinan pesanten dan mengajar kitab-kitab klasik kepada para santrinya. Sementara ulama adalah sebutan untuk ahli ahli pengetahuan Islam. Tetapi akhir-akhir ini seorang ulama yang cukup berpengaruh di mayarakat juga disebut "kyai" walaupun mereka tidak memangku pesantren. Sebutan ini sepengetahuan peneliti memang lebih populer dikalangan muslim tradisional. Tetapi beberapa ahli agama di kalangan kaum modernis juga desebut kyai ${ }^{45}$.

Elit Islam, yakni para kyai, ulama dan pemuka Islam dalam sejarah keIslaman di jawa memiliki peranan yang asangat penting, walisongo menjadi bukti nyata akan ketangguhan para elit Islam dalam menyebarkan Islam di tanah Jawa.

dalam konteks yang lebih kecil yakni di desa Palang, juga terdapat beberapa kiyai yang dengan sikap tidak kenal lelah dan secara terus menerus memberikan pengajaran terhadap masyarakat desa Palang, sebut saja K.H. Ahmad Mustofa dan pak kiyai Ali, mereka berdua adalah salah satu contoh elit muslim zaman dahulu yang berperan aktif dalam menyebarkan Islam di bumi Palang. Selain itu pada awal tahun 1990 an masyarakat desa Palang juga sudah mulai melakukan pembelajaran tentang Islam keluar desa atau yang lazim disebut mondok, banyak dari warga desa Palang yang mondok di Pondok Pesantren Sunan Drajat, Pondok Pesantren Lasem Jawa Tengah dan berbagai pondok pesantren lain. Jumlahnya dari tahun ke tahun semakin meningkat.

45 Zamakhsyari Dhofier, Tradisi Pesantren; Studi Tentang Pandangan Kiyai (Jakarta : LP3ES, 1985), 55-60. 


\section{Kesimpulan}

Tradisi manganan perahu sepertinya hal nya tradisi yang lain dalam masyarakat, yang merupakan warisan secara turun temurun dari nenek moyang. Masyarakat zaman sekarang tidak pernah tahu kapan awal mula tradisi tersebut dilakukan, namun mereka hanya secara rutin melakukannya sebagai bagian dari penghormatan terhadap yang sudah tua. Sesuai dengan nama tradisi tersebut yakni manganan perahu maka sudah bisa kita duga bahwa pelaksanaannya akan erat hubungannya dengan laut, dalam rangka prosesi pelaksanaan manganan perahu memang tidak bisa dilepaskan dari laut sebagai bagian penting dari pelaksanaannya. Selain itu tumpeng sebagai media pengucap syukur kepada Allah secara vertical dan sebagai pemersatu masyarakat desa Palang sebagai bagian dari manfaat horizontal. Dalam praktiknya di lapangan pelaksanaan manganan perahu dari wkatu ke waktu memang telah mengalami perubahan atau bisa dikatakan mengalami pergeseran. Tradisi atau kebudayaan memang tidak akan luput dari perubahan hal ini disebabkn karenan pelaku tradisi yakni masyarakat juga mengalami perubahan dari masa ke masa. Manganan perahu yang awal mulanya kental dengan nuansa ke Hinduan dan jauh dari konsepsi ke Islaman secara perlahan mulai menuju pada konsepsi Islam, hal ini bisa kita temukan dari beberapa benda yang dipakai dalam pelaksanaan manganan perahu. Pada zaman awal dahulu setiap kali pelaksanaan manganan perahu masyarakat selalu menggunakan kepala kerbau sebagai bagian dari prosesi, akan tetapi semenjak era semakin menguatnya nilai-nilai ke Islaman serta masyarakat juga semakin memahami ajaran Islam tradisi penggunaan kepala kerbau mulai tidak lagi dilakukan (sekitar tahun 1990 an). Tradisi niscaya akan selalu mengalami perubahan hal ini disebabkan karenan disikap dari pelaku tradisi itu sendiri yang tidak statis dan selalu berubah, terlebih juga terjadinya gesekan dengan tradisi lain juga ikut serta mempengaruhi perubahan suatu tradisi. Tradisi manganan perahu yang sudah dilakukan secara turun temurun juga tidak lepas dari perubahan, dari fakta yang di lapangan perubahan dari nuansa ke Hinduan menuju ke Islaman diyakini oleh masyarakat terjadi karena masyarakat sudah mulai mengenal Islam secara kaffah, serta nilai- nilai ke Islaman juga sudah mulai membumi di desa Palang, hal ini yang kemudian memberikan pengaruh pada proses pelaksanaan manganan perahu.

\section{Daftar Pustaka}

Abraham, Modernisasi di Dunia Ketiga; Suatu Teori Pembangunan, Ahli Bahasa : Rusli Karim, Yogyakarta: Tiara Wacana, 1991.

Agus, Bustanuddin, Agama dalam kehidupan Manusia, Pengantar Antropologi Agama, Jakarta: Raja Grafindo Persada, 2007.

Damami, Muhammad, Makna Agama dalam Masyarakat Jawa Yogyakarta: LESFI, 2002.

Dhofier, Zamakhsyari, Tradisi Pesantren; Studi Tentang Pandangan Kiyai Jakarta: LP3ES, 1985. 
Geertz, Abangan, Santri, Priyai dalam Masyarakat Jawa, Jakarta: Dunia Pustaka Jaya, 1981.

Gellner, Ernest, Menolak Post Modernisme Antara Fundamentalisme Rasinalisme dan Fundamentalisme Religius, Alih Bahasa: Hendro Prasetyo dan Nurul Agustina, Bandung: Mizan, 1994.

Harsojo, Pengantar Antropologi Jakarta: Abardi, 1984.

Haviland, William A., Antropologi, Jilid 1 Jakarta: Erlangga, 1985.

Huda, Mohammad Thoriqul,"Harmoni Sosial dalam Tradisi Sedekah Bumi Masyarakat Desa Pancur Bojonegoro”, Religio, Vol. 7 No. 22017

Khalil, Ahmad, Islam jawa, sufisme dalam etika dan tradisi jawa, UIN-Malang Press: SUKSES Offset, 2008.

Koentjaraningrat, Pengantar Antropologi; Pokok - pokok Etnografi Jakarta: Rineka Cipta, 1998.

Koentjaraningrat, Pengantar Ilmu Antrpologi Jakarta: Rineka Cipta, 1990.

Koenjtaraningrat, Sejarah Teori Antropologi I Jakarta: UI Press, 1987.

Koentjaraningrat, Kebudayaan, Mentalitas dan Pembangunan, Jakarta: Gramedia Pustaka Utama, 1993.

Masimambow, Koentjaraningrat dan Antropologi di Indonesia, Jakarta:Yayasan Obor Indonesia, 1997.

O'dea, Thomas F, sosiologi agama; suatu pengantar awal Jakarta: CV Rajawali, 1992.

Ranjabar, Jacobus, Sistem Sosial Budaya Indonesia; Suatu Pengantar Bogor: Ghalia Indonesia, 2006.

Saiful, Muzani, Pembangunan dan Kebangkitan Islam di Asia Tenggara Jakarta: LP3ES, 1993.

Sairin, Sjafri, Perubahan Sosial Masyarakat Indonesia Yogyakarta: Pustaka Pelajar, 2002.

Suryadi, Linus, SG, Regol Megal megol, Fenomena Kosmologi jawa, Jogjakarta: Andi Offset, 1993.

Tasmuji, Dkk, Ilmu Alamiah Dasar, Ilmu Sosial Dasar, Ilmu Budaya Dasar, Surabaya: IAIN Sunan Ampel Press, 2011. 